\title{
BEACH RESTORATION IN THE TARRAGONA COAST (SPAIN). SAND MANAGEMENT DURING THE LAST 25 YEARS AND FUTURE PLANS
}

\author{
Jordi Galofré, Ministry of A.F.F. and Environment, jgalofre@mapama.es \\ José A. Jiménez, Laboratori d’Enginyeria Marítima, UPC, jose.jimenez@upc.edu \\ Herminia I Valdemoro, Laboratori d’Enginyeria Marítima, UPC, herminia.valldemoro@upc.edu
}

\section{INTRODUCTION}

Erosion is the dominant behavior along worldwide coastlines. Although many factors can locally influence processes governing coastline evolution some common factors can be identified. Thus, the sediment budget has largely been modified in most of developed coasts, with river sand supplies being drastically reduced due to human influence in drainage basins. On the other hand, coastal segmentation due to infrastructures alters sediment transport patterns and induces and/or accelerates coastline erosion. Within this general context, artificial nourishment has become the most used coastal engineering measure by mimicking the role played by river sediment supplies to compensate local erosion problems. Since nourishment is not acting on the origin of the problems, erosive processes will continue to control shoreline evolution. Thus, the evolution of beach fills will be controlled by the sediment budget within the coastal cell where works have been done and, this will determine required sediment volumes to maintain the future shoreline.

Within this context, we present data on long-term (25 years) shoreline evolution and nourishment operations in the Tarragona coast (Spain, NW Mediterranean). The main aim of the work is to analyze the coastal stability and the effects of beach fills along the coast taking into account the type of the coastal cell where works have been implemented. Once this has been evaluated, the sustainability of an adaptation strategy based on the use of this protection measure to cope with climate change induced scenarios is also assessed to propose a longterm sediment management plan.

\section{RESULTS}

The first step consisted in defining littoral cells along the coast by identifying stretches bounded by anthropogenic and natural obstacles which can be considered as a single unit for littoral sediment transport (Figure 1). For each cell, coastline evolution has been characterized by analyzing aerial photographs covering the period from 1983 until 2016. Shoreline change rates were calculated for two different periods: 1983-1995 and 1995-2016, with the first period being analyzed by using the EPR method and, for the most recent period (1995-2016), by using the LR technique using a set of 7 aerial photographs. Table 1 shows the obtained shoreline rates of displacements for both periods. As it can be seen, during the first period the coastline shows an accretive behavior that becomes erosive during the second period. This change in shoreline evolution indicates a difference in forcing conditions controlling sediment budget during both periods.

Table 1 also shows the volume of beach nourishment operations in each cell during both periods. As it can be seen, most of sediment volume was supplied during the first period and, in this sense, their positive effect should be more visible when using the 1983 as reference. During this period most of the large beach nourishment operations took place, with some of them being designed to recover nearly fully eroded beaches (see also Galofré et al. 2015). On the other hand, during the second period, used volumes were simaller and mostly for beach maintenance. This variation in beach nourishment volumes in time and space will determine the change in allochthonous inputs to the coastal sediment budget. Net longshore sediment transport along this coast varies between $15,000 \mathrm{~m}^{3} / \mathrm{y}$ and $55,000 \mathrm{~m}^{3} / \mathrm{y}$ from east to west depending on the local coastline orientation and wave conditions. These transport rates determine the expected alongshore mobility with the integrity of the cell ends determining how much sediment will be lost for each unit. In addition to this, we also have to consider the potential role of offshore losses due to the imbalance of storm/post-storm cross-shore processes. When analyzing wave climate in the study area, the period between 1983 and 1995 wasi significantly milder in terms of wave energy than the period from 1995 until 2016, when some clustered stormy years were present (Jiménez et al. 2012).

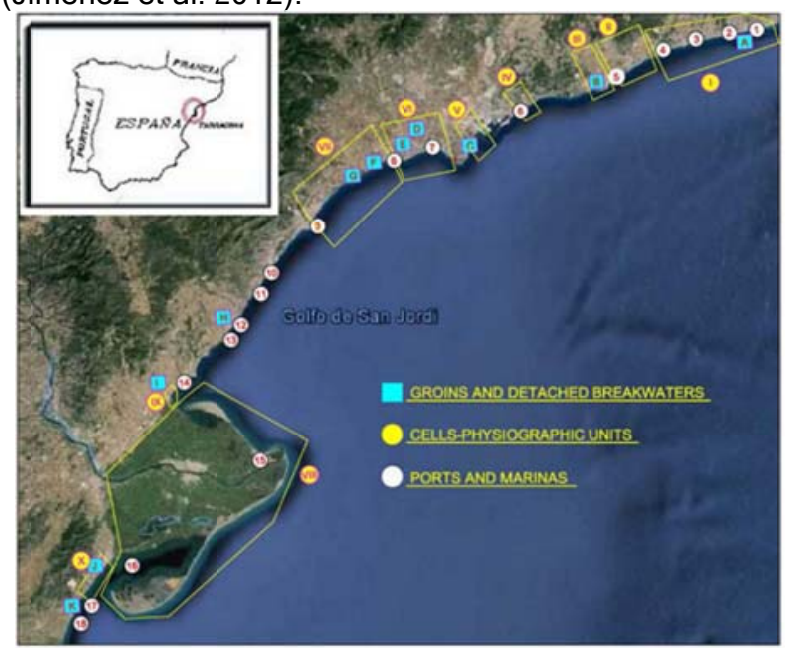

Figure 1 - Location of cells, ports an marinas, and protection beach works

\begin{tabular}{|c|c|c|c|c|c|}
\hline & \multicolumn{2}{|c|}{$1983-1995$} & \multicolumn{2}{c|}{$1995-2016$} & \\
\hline Cell & $\begin{array}{c}\text { EPR } \\
(\mathrm{m} / \mathrm{y})\end{array}$ & $\begin{array}{c}\text { Vol } \\
\left(10^{3} \mathrm{~m}^{3}\right)\end{array}$ & $\begin{array}{c}\text { LR } \\
(\mathrm{m} / \mathrm{y})\end{array}$ & $\begin{array}{c}\text { Vol } \\
\left(10^{3} \mathrm{~m}^{3}\right)\end{array}$ & $\begin{array}{c}\text { L sand } \\
(\mathrm{km})\end{array}$ \\
\hline I & 3.0 & 2,369 & -0.3 & 133.3 & 14.4 \\
\hline II & 1.0 & 396.5 & 0.0 & 60 & 6.6 \\
\hline III & 4.9 & 444.5 & -2.0 & 100.7 & 1.0 \\
\hline IIIa & 0.7 & 0 & -0.4 & 0 & 5.5 \\
\hline IV & 0.8 & 309.4 & -0.4 & 31.7 & 1.1 \\
\hline V & 2.9 & 0 & 1.4 & 23.1 & 2.6 \\
\hline VI & 1.6 & 788.1 & -0.1 & 479.7 & 8.1 \\
\hline VII & 1.8 & 871 & -0.2 & 479.9 & 12.4 \\
\hline VIla & 0.6 & 318.6 & -0.4 & 208.4 & 9.4 \\
\hline VIII & & & & & \\
\hline IX & -1.0 & 0 & -0.5 & 45.6 & 1.9 \\
\hline$X$ & 1.6 & 66.1 & 0 & 66.1 & 0.5 \\
\hline & & & & & \\
\hline total & 1.4 & $5,561.8$ & -0.2 & $1,628.6$ & 63.7 \\
\hline
\end{tabular}

Table 1 - Shoreline rates of displacements, nourishment volumes and length of sandy shorelines within each coastal cell. 
If we consider the second period as representative of current conditions in terms of wave climate and low sediment input, the expected long-term future shoreline behavior will be clearly erosive. In addition to this, under a highly probable scenario of climate change, expected sea level rise will induce additional background erosion and, in consequence, overall shoreline retreat rates will increase. This will imply that, in the case of selecting beach nourishment as protection measure to maintain shoreline along the study area, future needs of sediment volumes will increase with time. Estimated regionalaveraged SLR-induced shoreline retreat is about 0.5 to $0.75 \mathrm{~m} / \mathrm{y}$ (depending on the used scenario), which may produce the full disappearance of some beaches along the coast if no further action is taken (Jiménez et al. 2017).

In order to assess the sustainability of an adaptation strategy based on the use of beach nourishment we have estimated required volumes for different climate scenarios on the one hand and, existing borrow sediment resources on the other hand (both at sea and land). Main borrow areas presently identified in this coastal stretch are: Garraf marine sediment borrow area with an estimated volume of $1,250,000 \mathrm{~m}^{3}$, Mont-roig marine sediment borrow area with an estimated volume of $2,000,000 \mathrm{~m}^{3}$, and Baix Camp terrestrial sediment borrow area with a volume of $1,500,000 \mathrm{~m}^{3}$. If these amounts were the only available ones, its total amount is lower than the used during the last 25 years and, are also much lower than the required ones just to compensate SLR. In addition to this, it has to be considered that the dominant recreational use of beaches along this area, imposes the need of using quality sediment (mostly to be obtained by nearshore dredging) to manage shoreline retreat. This stresses the need to identify and quantify strategic sediment reservoirs to be used as borrow sites (Jiménez et al. 2011).

Taking into account the obtained results, the work will propose a sand management plan for the area taking into account the expected impact of shoreline erosion along the coast, identified sediment resources, the availability of the accommodation space and, policy priorities.

\section{ACKNOWLEDGEMENTS}

This work has been done in the framework of the $M$ CostAdapt (CTM2017-83655-C2-1-R) research project (MINECO/AEI/FEDER, UE).

\section{REFERENCES}

Galofré, Rojo, Mestre, Romero (2015) Balance de las arenas aportadas en las playas de Tarragona durante el período 1988-2012. XIII Jornadas Esp de Ing de Puertos y Costas, Avilés.

Jiménez, Gracia, Valdemoro, Mendoza, S-Arcilla (2011) Managing erosion-induced problems in NW Med urban beaches. Ocean \& Coastal Management, 54, 907-918.

Jiménez, Sancho, Bosom, Valdemoro, Guillén (2012) Storm-induced damages along the Catalan coast (NW Mediterranean) during the period 1958-2008. Geomorphology, 143-144, 24-33

Jiménez, Valdemoro, Bosom, Sánchez-Arcilla, Nicholls (2017) Impacts of sea-level rise-induced erosion on the Catalan coast. Reg Environ Change, 17, 593-603. 